\title{
A NEMZETI IDENTITÁS ALAKULÁSA A POSZTSZOVJET AZERBAJDZSÁNBAN
}

\author{
KŐSZEGI MARGIT - BOTTLIK ZSOLT \\ THE DEVELOPMENT OF NATIONAL IDENTITY \\ IN POST-SOVIET AZERBAIJAN
}

\begin{abstract}
Widely known for its diversity of peoples, the Caucasus is home to the so-called Transcaucasian states, which include Azerbaijan, Georgia, and Armenia. Formed as member republics of the Soviet Union in the early $20^{\text {th }}$ century, these nation-states became independent after 1990 . Though they in many ways owed their existence to Soviet policy, and of course also to Soviet power, the peoples of this region nevertheless regarded their countries as legitimate nations, and saw themselves as proud custodians of thousands of years of culture and statehood.

Like their neighbours, the Azerbaijanis have laid claim to a long history of civilization and development in the Caucasus. Beyond this, they also profess to live in the first democratic state of the Islamic world. This self-definition already carries in itself the peculiarities of their peripheral position, namely the hybridity of their collective identity (BHABHA, H. 2004). As part of Islam, but as a result of tsarist Russian expansionist efforts, they became involved in the process of forming "imagined communities" (ANDERSON, B. 1991) which resulted in the proclamation in 1918 of their short-lived independent nation-state. However, the formation of their national identity over the rest of the $20^{\text {th }}$ century was determined by Soviet-type state power, which meant the abolition of the role of religion in defining identity. The effects of the Soviet period, in addition to the nature of political leadership, also illustrates continuity in everyday life, even after the break-up of the Soviet Union, and in parallel with the revival of Islam.

Given its history in the short $20^{\text {th }}$ century, Azerbaijan understandably retains specific post-Soviet characteristics. This article focuses specifically on the effects of power, hegemony and leadership that determined the formation of the Azerbaijani nation. In terms of the national consciousness of Azerbaijanis more generally, the direct and indirect influence on the periphery by centralized leadership, whether Soviet or now Russian, is paramount.
\end{abstract}

Keywords: Azerbaijan, national identity, political power, Ngorno Krabakh

\section{Bevezetés}

A hétköznapi diskurzusokban népek kavalkádjaként ismert Kaukázus részét képezik az ún. transzkaukázusi államok: Azerbajdzsán, Grúzia, valamint Örményország. A térségbeli országokat összeköti az a sajátosság, hogy a Szovjetunió tagköztársaságaiként alakították ki őket a 20. század elején, majd annak széthullásával a korábban konstruált territóriumuk vált független nemzetállammá az 1990-es évek elején. Ugyanakkor a három ország nemzetként definiált népei több ezer éves kultúrájuk és államiságuk büszke letéteményeseiként tekintenek önmagukra. Közülük az azerbajdzsániak, saját bevallásuk szerint, az iszlám világ első demokratikus államában élnek.

Ez az öndefiníció már önmagában hordozza perifériahelyzetükből adódó sajátosságaikat. Az iszlám részeként, de a cári orosz expanziós törekvések következtében kapcsolódtak az „elképzelt közösségek” formálódásának folyamatába, amelynek eredményeként 1918ban kikiáltották rövid életú független nemzetállamukat. Nemzeti identitásuk formálódását azonban a 20. század további részében a szovjet típusú államhatalom határozta meg, ami a politikai vezetés jellegén túl a mindennapokban is kontinuitást mutat a Szovjetunió felbomlása és a függetlenség elnyerése után is. 
A szovjet időszak hatásai közül a nemzeti identitás formálódásában külön jelentőséget kap a határok kialakításából következő területi alapú vita Hegyi-Karabah kapcsán a szomszédos Örményországgal, ami már az 1980-as években kiélezte a feszültségeket, majd még a szovjet érában, 1988-ban fegyveres konfliktussá alakult a két ország, valamint Azerbajdzsán többségi nemzete és a kisebbségben elő örmények között. A sokáig befagyott konfliktus utoljára 2020 őszén éleződött ki, amely kishíján háborúvá terebélyesedett Azerbajdzsán és Örményország között. A közös ellenfél és a veszélyeztetett területi integritás különösen erős hatótényezőt jelentett az azerbajdzsáni nemzettudat alakulásában a függetlenség elnyerése utáni években.

Ugyanakkor nem szabad elfelejtkezni arról sem, hogy a jelenlegi Azerbajdzsán határain kívül több millió azeri nyelvü, siíta muszlim lakosság él. E közösségek közül a legnagyobb az ország déli határain túl Iránban (többek között a Kelet- és Nyugat-Azerbajdzsánnak nevezett szubacionális területi egységekben) lakó több mint 18 millió fó, ami majd két és félszer több mint Azerbajdzsán azeri lakossága (Ulasıuk, I. 2013) (1. ábra). A szovjet időszakban széles körben elterjedt összeesküvés-elmélet miatt, miszerint az azeri népet szándékosan vágták ketté az osztozkodó hatalmak (az Orosz és a Perzsa Birodalom), a közvélekedésben felerősödött az összetartozás tudata a határ túloldalán élő azeriekkel, ami a rendszerváltás pillanatában határmenti konfliktusokhoz, esetenként illegális határátlépésekhez vezetett. Ez a jelenség a posztszovjet azerbajdzsáni hatalmi elitet - a fent említett területi alapú konfliktusából adódóan - érzékeny válaszút elé állította.

Szintén a Szovjetunióhoz köthető az az erőltetett iparosítás, ami a legjelentősebb gazdasági tényezôvé emelte az ország stratégiai jelentőségú szénhidrogén vagyonát. Az anyaföld-

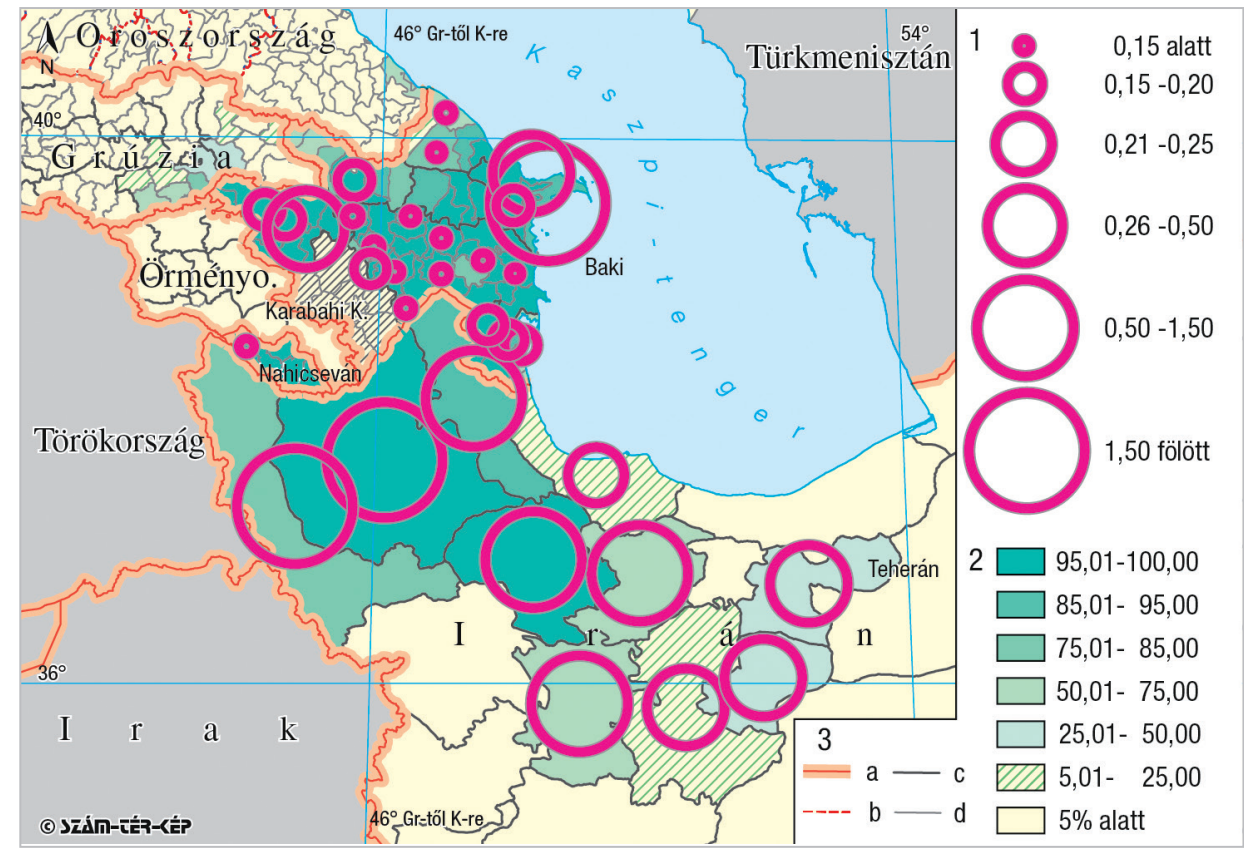

1. ábra Az azeriek száma és aránya 2011-ben

Jelmagyarázat 1- Az azeriek száma (millió fő); 2- Az azeriek aránya (\%); 3- Határok, a- országhatár, b- autonóm körzet határa, c- oblasztyhatár/provinciahatár, d- rajonhatár

Figure 1 The number and proportion of Azeris in 2011

Legend 1- Size of Azeri population (million prs.); 2-Percentage of the Azeri population (\%); 3- Boundaries, a- State boundary, b- Boundary of Autonomous territory, c- Oblast/Province boundary, d- Raion boundary 
höz kötött, ezért nemzeti kincsnek tekintett energiahordozó szélsőségesen meghatározza a modern Azerbajdzsán gazdaságát, ezáltal az itt élők megélhetését, mindennapjait, így a 21. századi azerbajdzsáni nemzeti mivolt szerves részét képezi.

Összességében elmondható tehát, hogy az azerbajdzsáni nemzet sajátos posztszovjet jellemzőkkel bír, amelyeket alábbi tanulmányunkban szeretnénk röviden bemutatni. Kifejezetten azokra a sarokpontokra fókuszálunk, amelyek a hatalom oldaláról határozták meg az azeri nemzet formálódását. Az azerbajdzsáni nemzettudat esetében (ahogy több más posztszovjet példa esetében is) a mindenkori orosz és szovjet központi vezetés a periférián érvényesülő közvetlen és közvetett befolyása érvényesül.

\section{Az elképzelt azerbajdzsáni közösség formálása}

Az azerbajdzsáni nemzeti identitás vizsgálatakor elfogadjuk azt a szemléletmódot, hogy a nyomtatáskapitalizmus elterjedésével, valamint a modernizáció további, kommunikációt segítő hatásainak minél szélesebb körű érvényesülésével, illetve a hatalom által múködtetett közigazgatási és oktatási intézmények hatékony szervezésével egyre szélesebb lehetőség nyílik a nemzeti közösségek kialakítására és formálására (ANDERSON, B. 1991). Ugyanakkor figyelembe vesszük azt az institucionlaista megközelítést is, ami a szovjet utódállamokban a nemzeti mivoltot intézményesült formaként, gyakorlati kategóriaként és esetleges eseményként értelmezi (BRUBAKER, R. 1996). Nézópontunkat formálta továbbá a nemzetek etnikai jellegének, valamint ennek hatalmi konstrukciókhoz való viszonyulásának elméleti megalapozása is (ERIKSEN, T.H. 2003). Az azerbajdzsáni nemzeti mivolt posztszovjet jellemzőinek vizsgálatával kapcsolódni kívánunk azokhoz a kutatásokhoz, amelyek a posztszocialista és posztszovjet kifejezések tudományos beágyazottságát segítették elő az elmúlt évtizedekben. Vizsgálatunkban nem időt és teret behatároló tartályként vagy átmeneti időszakként értelmezzük a posztszovjetet (TUVIKENE, T. 2016). Sokkal inkább arra helyezzük a hangsúlyt, hogy e térbeli és időbeli kapcsolódások keretrendszerében az egyes folyamatok és jellegzetességek - jelen esetben az azerbajdzsáni nemzeti identitás - jellemzőit lehet posztszovjetként értelmezni.

Mindezen elméleti alapvetések mentén, a rendelkezésünkre álló szakirodalom segítségével végrehajtott diskurzuselemzés révén vázoljuk fel az azerbajdzsáni nemzeti identitás formálódásának folyamatát. Vizsgálataink segítségével kívánunk rávilágítani az orosz expanzió nyomán megjelenő modernizáció azerbajdzsáni nemzeti közösséget formáló hatásaira. Orosz és szovjet nemzetépítő sajátosságok egyértelmú különválasztásával hívjuk fel a figyelmet azokra az etnikai sajátosságokra, amelyek a szovjet típusú nemzeti identitáskonstrukciók révén erősödtek meg az azerbajdzsáni közösségekben (CoRNELL S. E. 1998, 1999). Ez utóbbiak szerepét hangsúlyozzuk a Hegyi-Karabah kapcsán kibontakozó fegyveres konfliktus hátterének bemutatásakor is. Ugyanakkor a szovjet típusú modernizáció hatásai nyomán átalakuló azerbajdzsáni társadalom sajátosságaira is hangsúlyt fektetünk. A szovjet időszak komplex hatásmechanizmusainak feltárása, valamint Azerbajdzsán ezredfordulós geopolitikai helyzetbe ágyazása révén mutatunk rá a 21. századi azerbajdzsáni nemzettudat posztszovjet sajátosságira.

\section{A cári orosz hatalom megjelenése és hatásai Azerbajdzsán területén}

A mai Azerbajdzsán teljes területének Oroszországhoz csatolása a 19. század első felében következett be. Szimbolikus jelentőségét adja egyrészt az, hogy a „keleti kérdésként” emlegetett nagyhatalmi játszmák árnyékában történt. Míg azonban az Oszmán Birodalom 
jövője az európai kontinentális egyensúly szempontjából fontos kérdés volt a nyugati hatalmak számára, a Perzsa Birodalom rovására történő orosz terjeszkedés ekkor még parciálisnak számított. Ugyanakkor a 19. század második felében viszont az ún. „Nagy Játszma” révén már a perzsák keleti szomszédai kerültek fókuszba. Másrészt viszont összefüggésben állt a cári hatalom megdöntésének orosz nacionalista jellegű mozgalmával, az ún. dekabrista felkeléssel is (1825), amely arra sarkallta a perzsa vezetést, hogy támadást indítson a Jermolov tábornok vezette kaukázusi orosz hadsereg ellen. A perzsa hadsereg azonban katasztrofális vereséget szenvedett az immáron Paszkevics tábornok vezetése alatt álló orosz katonai erőktől, ezért a perzsa sah területveszteségekkel és az orosz befolyás növekedésével járó békekötésre kényszerült 1828. február 13.-án Türkmencsaj városában. Ez nemcsak megerősítette a korábbi 1813-as orosz-perzsa (Gülistan) békekötés orosz területi nyereségeit, hanem még további jelentős területek kerültek át orosz fennhatóság alá, illetve alakult ki a mai határ futása Azerbajdzsán és Irán, valamint Örményország között (HoRvát, Cs. 2011). A perzsa állam feldarabolásának terve ek kor azért nem valósult meg, mert a legitim uralkodó isteni elrendelésének és sérthetetlenségének egyik utolsó európai képviselője, I. Miklós nem egyezett bele a törvényes perzsa uralkodó hatalomfosztásába.

Ugyanakkor a fent említett békekötésekkel eldőlt, hogy Perzsia hatalmi tényezőként kiszorult a Kaukázus területéról a cári expanzió nyomására. A perzsa hatalomvesztés folyamata ennek következtében gyorsult fel: a Kaukázus északkeleti előterében fekvő, muszlim többségú Dagesztán elvesztése után a mai Grúzia teljes területe, valamint a mai Azerbajdzsán északi része került cári fennhatóság alá, végül 1828-ban kialakult Irán mai napig létezó északnyugati határa az Araksz (Arasz) folyó mentén. Ezzel több évszázados perzsa hatalmi befolyás szűnt meg a térségben, amelynek legfontosabb kulturális hozadéka, a síita iszlám és a perzsa nyelv jelenléte a mai napig tetten érhetô az azerbajdzsáni közösségek életében. Míg utóbbit az orosz nyelv a 20. században szinte teljesen kiszorította, addig az előbbi újfent markáns tényezője az azerbajdzsáni nemzeti identitásnak is.

Ugyanakkor a geopolitikai befolyás változásában az orosz hatalmi tényező fokozatos térnyerése már a 18. századtól érzékelhető a Kaszpi-tenger nyugati előterében. Közel száz évvel korábban, I. Péter uralkodásának végén már született egy békeszerződés oroszok és perzsák között, ami a tengermelléket és Baku városát is átengedte a hatalmas haderôvel (de óriási áldozatokkal) operáló cárnak. A meghódított területet a kibontakozó orosz-oszmán háborúk okán taktikai okokból ugyan ismét átengedték a perzsáknak, de az orosz befolyás erősödése folyamatos maradt a század végéig. Az uralkodása alatt nagyszabású expanziós terveket megvalósító II. Katalin idejében újra felvetődött a Kaszpi-tenger nyugati előterének Orosz Birodalomhoz csatolása. Megvalósításának csak a cárnő halála vetett véget, de a fentiek ismeretében a hódítás végül nem sokat váratott magára. Az Orosz Birodalom történetét megíró Mihail Heller I. Péter és II. Katalin a perzsák rovására bekövetkező hódításai kapcsán is a gazdasági jellegú szándékot hangsúlyozta: az India felé kiépítendő kereskedelmi kapcsolatok igényét (HELLER, M.-NYIKERICS, A. 1996). Ennek szellemében a két központi szerepkört betöltő és jelentős kikötőforgalmat lebonyolító város, a dagesztáni Derbent, valamint a későbbi azerbajdzsáni fôváros, Baku, már a 18. század végén orosz kézen volt.

Az Orosz Birodalom területgyarapodása jelentős migrációt indított el a megszállt területekről Perzsia irányába. Néhány évtizedes katonai közigazgatás után, a 19. század második felében a mai Azerbajdzsán területén két kormányzóságot hoztak létre, amelynek központjai a térség jelentős városai voltak: az Erzsébet cárnéról elnevezett Jelizavetpol (a korábbi Gandzsa/Ganja), valamint a Kaszpi-tenger legnagyobb kikötője, Baku (O’LoughLIN, J.-Kolossov, V.-RADVANYI, J. 2007). A 19. század első felének orosz kormányzata, és ezzel együtt a hatalom közvetítésének eszköz- és eljárásrendszere átmenetnek tekinthető 
a korábbi kánságok és a cári birodalmi közigazgatás között. Az iszlám szokásjog érvényesülésének területe fokozatosan szorult vissza a családok szintjére, miközben a keresztény alattvalók egyértelmú előnyt élveztek muszlim társaikkal szemben. Utóbbiak az eszközeikben nem válogató orosz térítők célpontjaivá is váltak. Az eltérő bánásmód és a vallási megkülönböztetésből eredő feszültségek különösen a városokban vezettek etnikai ellentétek éleződéséhez: az örmény-azerbajdzsáni szembenállás az orosz hatalom kiépítésével, valamint a modernizáció megjelenésével párhuzamosan mélyült el. A cári adminisztráció keresztényeket támogató politikájának köszönhető az is, hogy az orosz fennhatósággal jelentős örmény beáramlás is történt, ami lazította sok helyen a muszlim tömböket és növelte az örmény településterületeket a dél-kaukázusi régióban. (Ezt a mai azeri kontextusban egyértelmúen muszlim ellenes ténykedésnek tekintik (GASIMOV, Z. 2013).) Ennek a folyamatnak az eredménye az azeri-örmény lakosság nagyfokú keveredése a 19. század utolsó harmadára (2.ábra).

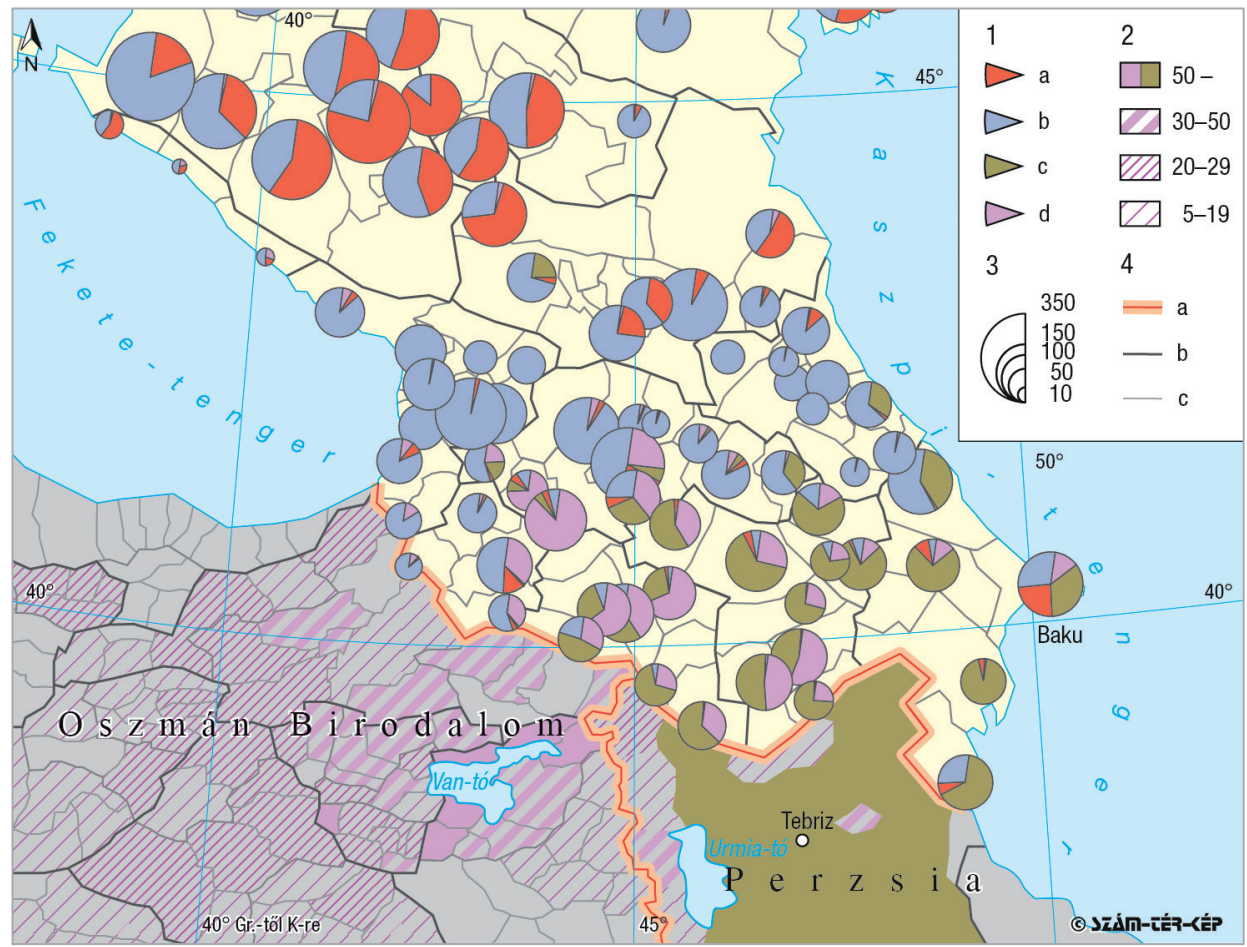

2. ábra Az azeri és örmény etnikai terület a 19. század végén (1896/1897)

Jelmagyarázat: 1- A lakosság etnikai/nyelvi összetétele; a- orosz, b- minden egyéb, c- azeri, d- örmény; 2- Az Oroszországon kívüli örmény/azeri etnikai terület;

3- A lakosság száma (1000fó); 4- Határok; a- országhatár, b- kormányzóság határa, c- rajonhatár

Figure 1 The ethnic territory of Azerbaijan and Armenia in the late 19th century (1896/1897)

Legend: 1- Ethnic composition of the population; a- Russian, b- all other, c- Azerbajani, d- Armenian; 2 - Ethnic territory of azeri/armenian outside Russia;

3- Size of population (1000 prs); 4- Boundaries; a- State boundary, b- Governorate boundary, c- Raion boundary

Az orosz hatalmi tényező területi effektusainak érvényesülése szempontjából Baku változása a leginkább szembetúnő. A kikötőváros kereskedelmének fellendítésével már a 19. század első felében megindult a település bővítése, átépítése, arculatának megváltozása. A kőolaj miatt a város gazdasági jelentőségének növekedésével egyre több bevándorló tele- 
pedett le itt az Orosz Birodalom különböző részeiből. A gazdasági növekedés és a népességgyarapodás különösen az 1870-es évektől vált intenzívvé, a kőolajlelőhelyek feltárása és a kitermeléshez, valamint feldolgozáshoz szükségek iparágak megjelenésének hatására. Itt fúrták a világ első olajkútját (1846) amit röviddel ezután kőolajfinomító (1859), illetve petróleumgyártó üzem építése követett (1863). Az olajipar felfutása a közlekedés (például a transzkaukázusi vasút) és az egyéb szolgáltatások kiépülését, a tömegkommunikáció felfutását vonta maga után, miközben munkaerő-igénye révén a birodalom minden területérôl és a szomszédos Iránból is vonzotta a dolgozókat. Baku multikulturális várossá alakulására azonban rányomta az árnyékát a muszlimok háttérbe szorítása: a tulajdonosi kör fơként a (keresztény) orosz és örmény befektetôkből került ki.

A gyors gazdasági felfutás és az egyoldalú fejlesztés sérülékennyé is tette az új olajipari központot, ami 20. század elején, az elhúzódó orosz-japán háború nyomán kibontakozó gazdasági válsággal azonnal éreztette is a hatását. A munkanélküliség növekedésével az etnikai feszültségek is felszínre kerültek, ami muszlim-örmény összecsapásokhoz vezetett. A cári vezetés az ellentétek fenntartásában hatalmának zálogát látta, ezért többször utat engedett az egymás elleni erőszaknak (RAUF A. G. 1996).

A gyors modernizáció révén a világ felé nyitottabbá váló transzkaukázusi kormányzóságokban világnézeti változások is történtek. Az orosz és oszmán világgal való közvetlenebb kapcsolat a radikális társadalmi ideológiák terjedését is magukkal hozták. A század elején például a bakui munkássztrájkok szervezésével hívta fel magára a figyelmet többek között a kommunizmus ideológiáját hirdető és az olajmágnások elnyomó hatalmát bíráló Sztálin, de párttársa és barátja, a szintén grúz származású Ordzsonikidze is dolgozott itt. A muszlimokkal szembeni negatív megkülönböztetés közösségformáló erejét radikális azerbajdzsáni értelmiségiek fordították a nacionalista jellegű mozgalmak irányába, amelyek a térség muszlim lakosságának érdekérvényesítéséért küzdöttek. Mindezek alapján elmondható, hogy az azerbajdzsáni nemzeti identitás, illetve a csoporttudatot veszélyesztető ellenségképek, bevezetőben említett alapvetô elemei már a 19. században jelentkeztek, az orosz cári hatalom által generált társadalmi változások hatására.

Ugyanakkor a vidéki közösségek, illetve részben a fenti iparosítás által kevésbé érintett városi muszlim közösségek (pl. Tbiliszi, Gandzsa) mindennapjaiban még kevésbé érvényesültek a társadalmi változások. Az iszlám vallási ideológia határozta meg továbbra is az itt élők életét. A patriarchális társadalmi berendezkedés a tradicionális női szerepeket és öltözködési szokásokat preferálta, nehezen engedve utat a cári orosz modernizációs törekvéseknek az oktatásban és a közéletben (NAJAFIZADEH, M. 2012). Ezzel ellentétben a városi, különösen a bakui muszlim közösségek nyitottabbak voltak az európai kulturális hatásokra, ami érzékelhető volt a szekularizáció erősödésében és a nyugati módon értelmezett női szerepek térnyerésében is. Felvilágosult muszlim gondolkodók és filantrópok (pl. az író, filozófus Mirza Fathali Akhundov, vagy az iparmágnás Haji Taghiyev) révén a muszlim közösségen belül is megjelent az új keretekhez való igazodás és a benne való érvényesülés igénye.

\section{Az önálló Azerbajdzsán létrejöttének körülményei}

Az orosz forradalom kitörése és a cári hatalom megszúnése függetlenségi mozgalmakhoz vezetett az Orosz Birodalom európai perifériaterületein, amelyek szervesen illeszkedtek az első világháború nagyhatalmi kontextusaiba. A forradalmi Oroszországban széteső struktúrák gyengítették a perifériaterületek orosz hatalommal való kapcsolatát és aktivizálták más hatalmi érdekek érvényesülését is. Az oszmán befolyás erősödése mellet az intervenció időszakában angol felvonulási területnek számított a Kaukázus, de miután 
jelentôs katonai erőt egyikük sem tudott a térségbe koncentrálni, az így kialakuló átmeneti állapot a Kaukázuson túli területek számára is a függetlenedés lehetőségét hordozta. Ezt pedig a formálódó radikális értelmiség által indított tömegmozgalmak meg is valósítottak. Az ún. Transzkaukázusi Köztársaság az oszmán veszély elhárítására, elsősorban keresztény grúz és örmény kezdeményezésre jött létre. A jelentős létszámú muszlim lakosság eltérő érdekei, valamint a fennálló helyzetet értékelő politikai véleménykülönbségek miatt a regionális szerveződés magában hordozta az etnikai jellegú ellentéteket is, amelyek az önálló nemzetállamok kialakulása előtt nyitották meg az utat. A nacionalista jellegú mozgalmak így sikerre vezettek 1918-ban: május 28.-án kikiáltották az Azerbajdzsáni Demokratikus Köztársaságot.

Az új állam, a mainál nagyobb, de közel azonos területen jött létre, nyugati határai azonban tisztázatlanok voltak. Nevét a szomszédos Perzsia északnyugati tartományaiból kölcsönözte, ahol már létezett a közigazgatási beosztásban Kelet- és Nyugat-Azerbajdzsán. A névválasztással tehát egyben sorsközösséget is vállaltak a perzsa fennhatóság alatt élő, azeri türk nyelven beszélő lakossággal, akik jelentős többséget alkottak Perzsia északnyugati régiójában. Ugyanakkor arra is utaltak, hogy a muszlim hívő lakosság dominanciájával és vezetésével alakult meg az új nemzetállam a Kaukázusban. Baku városának keresztény (fóként örmény és orosz) vezetése és lakossága azonban nem fogadta el a terület szuverenitását. A bakui olajmunkások körében a bolsevikok jelentős tömegbázissal rendelkeztek, ami viszont arra sarkallta a briteket, hogy a vörös veszély elhárítása érdekében elfoglalják a várost. A kibontakozó küzdelmekben gyakran a város muszlim lakossága vált célponttá, azonban a váltakozó eróviszonyok közepette az etnikai ellentétből fakadó összecsapások mindkét fél részéről jelentős áldozatokat követeltek. Baku végül oszmán katonai segítséggel vált az új köztársaság fővárosává. Ez a segítségnyújtás az Oszmán Birodalom utódjaként létrejövő Törökországgal való baráti kapcsolatok ápolásának vált kikezdhetetlen alapjává az újra függetlenedő posztszovjet Azerbajdzsánban is.

A parlamentáris demokrácia múködésben a liberális, a szociáldemokrata, a konzervatív nézőpontok egyaránt helyet kaptak, ami jelzi a társadalom fokozódó modernizálódását, és az állam beágyazottságát az európai keretekbe. A párizskörnyéki békékben az Azerbajdzsáni Demokratikus Köztársaság is részt vett, tehát de facto is elismerte a nemzetközi közösség független államként, de az ujonnan megalakult államok vezetőinek többsége, illetve politikájuk is Európa felé tekintett. Ugyanakkor az orosz polgárháborúból 1920-ra győztesként kiemelkedő bolsevik hatalom egyértelmú fenyegetésként jelent meg a térségben, ami rövidesen katonai támadásokban is realizálódott. A,,vörösök” konkrétan újra elfoglalták a korábbi Orosz Birodalomhoz tartozó kaukázusi területeket. A háború azerbajdzsáni részről rengeteg áldozatot követelt, ugyanakkor katonai erejüket megosztani kényszerültek: Hegyi-Karabah (e fogalmat a világ közvéleménye az 1990-es években ismerhette meg szélesebb körben (YAMSKOV, A. N. 1991)) területén ugyanis ekkor folyamatosan szerveződtek fegyveres felkelések, miközben nyugati határainak tisztázása háborús konfliktust eredményezett a szomszédos Örményországgal, amely az Azerbajdzsáni Demokratikus Köztársasággal egy napon jött létre. Az örmény-azeri viszonyt tovább feszítette az egykori Oszmán Birodalomban bekövetkezett, örményekkel szembeni fellépés, ami migrációt indított el körükben a Kaukázus felé (MutLu, S. 2003).

A Vörös Hadsereg 1920. április 28.-án a későbbi kaukázusi kommunista közigazgatás kiépítését vezető Szergej Kirov, valamint Grigorij Ordzsonikidze részvételével megszállta előbb az Azerbajdzsáni Demokratikus köztársaságot, majd Örményországot, végül pedig Grúziát. Ugyanakkor azt is fontos hangsúlyozni, hogy a kommunizmus ideológiájának helyben is volt tömegbázisa, különösen a bakui munkások körében, így a véres háború után a kommunista hatalomátvétel jelentősebb ellenállás nélkül megtörténhetett 
Azerbajdzsánban. Az első világháború átmeneti időszakában tehát nyilvánvalóvá vált, hogy továbbra is a moszkvai hatalmi központ határozza meg az Arasz-folyótól északra élő azerbajdzsánok életét, és ezzel együtt az azerbajdzsáni nemzetépítés folyamatát, illetve annak későbbi lehetőségeit is.

Ugyanakkor a bolsevikok az első világháború után igen aktívan léptek fel a határ másik oldalán, Irán északnyugati részén is. Az ennek nyomán kibontakozó „,kommunista” mozgalom - a korenyizácija (meggyökereztetés) politikájával összhangban - az azeri csoport különállását hangsúlyozta. Ennek hátterében a kommunista ideológia terjeszkedésének vágya és az iráni síita muszlimokra gyakorolt hatásának gyengítése húzódott. A perzsa iskolahálózat gyengesége az iráni Azerbajdzsánban a helyi társadalmak viszonylag gyenge kapcsolatát is jelentette Teherán (Irán) felé. Ez a helyzet egyrészt sajátos módon erôsítette az azeri nemzettudatot a szovjet időkben is, másrészt a rendszerváltást követően ezt a posztszovjet azerbajdzsáni vezetés „nemzeti demokratikus felszabadító harcként” interpretálja, kifelejtve ezen mozgalmak egyébként internacionalista, bolsevik jellegét (GASIMOV,Z. 2013).

\section{Az azeri identitás az Azerbajdzsáni Szovjet Szocialista Köztársaságban}

A szovjet időszak nemzetiségpolitikáját meghatározó ideológiai kettősség, a népek önrendelkezési jogának érvényre juttatása, valamint a világforradalom jövőbeni győzelme érdekében egyben tartott centralizált, többnemzetiségű állam hatékony múködtetésének elve a bolsevik hatalom megszilárdításával, valamint Lenin betegségével és Sztálin hatalmának növekedésével egyre inkább a centralizáció irányába tolódott el. Az Orosz Föderáció és a szovjet tagköztársaságok közötti viszony rendezésének mintaokmánya lett később az a szerződés, amit 1920. szeptember 20.-án írtak alá Azerbajdzsánnal (HeLlER, M.-NyEKRICS A. 1996). A megállapodás rendkívül szoros katonai, valamint gazdasági és pénzügyi szövetségről (tulajdonképpen a szerződők területeinek egyesítéséről és intézményrendszerének összeolvasztásáról) szólt, továbbá gyakorlatilag megfosztotta a tagállamot az önálló belpolitikától, miután Moszkva folyamatosan beavatkozott a tagköztársaság belügyeibe. A lenini elvek érvényesülése tette lehetővé, hogy 1922-ben még a föderalizáció jelszavával biztosították az egyes tagköztársaságok szuverenitását és tartották fenn jogukat az esetleges kiválásra, de Lenin halálával és Sztálin hatalmának megszilárdulásával ennek gyakorlati jelentősége rohamosan csökkent. Sztálin a kezdetektől következetesen alkalmazta a kommunista ideológián alapuló érvrendszerét, amiben az iparosodottabb központi területek munkásosztályára támaszkodva tartotta megvalósíthatónak a paraszti dominanciájú periféria átformálását (Heller, M.-NyeKrics A. 1996). Ez a Moszkva-központúsággal jellemezhetô nézőpont Azerbajdzsán esetében nem csak a külső irányítás érvényesülését, hanem a korábban már végletesen eltávolodó főváros és vidék eltéró megítélését is maga után vonta. A drasztikus politikai változások fóként a vidéki társadalom életében okoztak nagy horderejü változásokat azzal, hogy az iszlám alapokon nyugvó közösségszervezést megszüntették, valamint a tradicionális családszerveződést alapjaiban felforgatták a nők munkába állításával (NAJAFIZADEH, M. 2012).

Az 1920-as évekre jellemző fent már említett korenyizácija politikájával az Azerbajdzsáni Szovjet Szocialista Köztársaságban (Azerbajdzsáni SZSZK) is lehetőséget teremtettek helyi megbízható pártkáderek felemelkedésének, akik segítséget nyújtottak a lakosoknak a szovjetrendszer és a marxista-leninista ideológiák hatékony befogadásában. Ebben az időszakban tehát igen fontos szerep jutott a fiatal, radikális értelmiségieknek, akiknek főként a helyi kultúra megteremtésében engedélyeztek széleskörú érvényesülést. Az elvnek, hogy minden tagköztársaságnak saját önálló nyelvvel kellett rendelkeznie, a perifériaterü- 
leteken, így a Kaukázusban is kettős szerepe volt. Egyrészt a kommunizmus ideológiáját olyan nyelven kívánták terjeszteni a helyi lakosok körében a nyomtatott sajtón és a modernizált, központosított oktatási rendszeren keresztül, hogy az mindenki számára érthető legyen. Ugyanakkor a tagköztársaságok saját anyanyelvének következetes előtérbe helyezése elősegítette, hogy a perifériaterületeken jelentőségüket veszítsék a korábban használatos, államokat összefogó egységes közvetítő nyelvek - így a Kaukázusban a perzsa - használata az orosszal szemben. Ez egyben távolította (Moszkva felé fordította) a lakosságot a határ túloldalán élő hasonló nyelven, hasonló kultúrával rendelkező csoportoktól is, ugyanakkor egy sajátos két(több)nyelvú környezet formálódott (PrAVIKOVA, L.-LAZAREV, V. 2005). Ebben a folyamatban hasonló szerepet töltött be a nemzeti történelmek konstruálása is, amellyel bizonyítani lehet a periféria népeinek különállását az életüket korábban meghatározó nagyobb államalakulatoktól - Azerbajdzsán esetében főként a Perzsa Birodalomtól.

További tényezőként kell megemlíteni Azerbajdzsán kapcsán, hogy a korenyizácija politikája egyben az iszlám vallási identitás teljes megszüntetését is célozta, amiben nem csak a szovjet típusú oktatási és közigazgatási rendszer bevezetése, hanem az etnikai alapokat építő államnyelv és módosított kollektív emlékezet (a nemzeti mítoszok) is eszközként szolgált (O’LEAR, S. 2008). Lelkes helyi pártkáderek segítették a váltást (pl. az oktatásügyi népbiztos, Mustafa Kuliev), igazolva ezzel a gyökereztetés politikájának hatékonyságát. A szekularizáció és az iszlám tradíciók elvetésének látványos formáját jelentette a mecsetek lerombolása, vagy éppen áruházakká, közösségi terekké alakítása (NAJAFIZADEH, M. 2012). Míg 1929-ben 1360 mecset múködött Azerbajdzsán területén, 1933-ra a számuk már csak 17 volt (NAJAFIZADEH, M. 2012). Az iszlám visszaszorulását jelentős mértékben segítette a Korán és más arab nyelvű szövegek eltüntetése, ami amellett, hogy nem voltak elérhetők, a régi példányok puszta birtoklása is büntetést vont maga után. Így az azerbajdzsánok zöme nem tudta megtanulni az arab/perzsa szövegek olvasását. Így az iszlám tradíciók átadása csak szúk családi körben, szóbeli közlés alapján volt lehetséges. Ennek következtében a vallás a hatalom szempontjából társadalmi perifériára szorult és egyre kevésbé volt kapocs az Iránban élő azerbajdzsániakkal, illetve általában a muszlim világ egészével.

Azerbajdzsán a törökkel szembeni magasfokú kölcsönös érthetőséggel rendelkező államnyelvének időben változó kulturális sajátosságait tükrözi az a tény, hogy írásmódja négyszer változott a 20. század folyamán. A század elején még arab írásjeleket használtak az azeri nyelv leírásakor, amit az 1920-as évek szovjet politikája módosított latinbetús átírásra. Az 1930-as évek erőteljes központosító intézkedései a cirillbetűs váltást hozták, ami végül a Szovjetunió felbomlásáig megmaradt (az 1990-es években viszont az új független állam geopolitikai orientációjának manifesztumaként a latin betűs írásmódra tért vissza).

A szovjet tagköztársaságok látszólagos önállósága ugyan a szúkebb és még szúkebb keretek között érvényesült a Szovjetunió fennállása alatt, de a fent említett kulturális önállóság a későbbi évtizedekben is jellemző maradt igaz, folyamatosan változó intenzitással. Ugyanakkor a Sztálin által is képviselt ideológiai elvek gyakorlati megvalósulása megmutatkozott a tagköztársaságokba bevándorló idegen, főként orosz munkásokban és az általuk képviselt kulturális hatásokban, valamint a rendszer keretei között értelmezhető társadalmi felemelkedés zálogaként is felfogható szovjet iskolarendszer jelenlétében. Az orosz nyelv ismerete és az orosz anyanyelvűek által képviselt modern életmód elsajátítása, valamint a hozzájuk kapcsolódó kulturális hatások befogadása jelentősen módosította a többségi lakosság kollektív identitástudatát, erősítve a moszkvai központhoz való kötődést, valamint az ún. spontán russzifikáció folyamatát. Az iszlám révén korábban a kollektív identitásban jelen lévő arab és perzsa elemeket az orosz kulturális hatás váltotta fel. Ennek manifesztumaként - főként a városi lakosság körében - a szovjet időszakban általánossá vált az orosz nyelv használata (O’LEAR, S. 2008). 


\section{Hegyi-Karabah és a „Másikkal” szembeni azerbajdzsán öndefiníció}

Amikor az 1990-es évek elején a Szovjetunió megszűnt létezni, az azerbajdzsáni politikai elit jelentősebb változtatások nélkül mentette át hatalmát a megváltozott geopolitikai helyzetben. A legfelsőbb vezetés döntése alapján már 1990 végén elhagyták az ország hivatalos nevéből a szovjet és szocialista jelzóket, módosították az állami jelképeket (többek között visszaállították az 1918-as zászlót). Az elnöki tisztség létrehozása után választások útján jelölték ki a vezetô személyét, majd 1991-ben népszavazás is megerôsítette az Azerbajdzsáni Köztársaság függetlenségét. A Szovjetuniótól függetlenedő Azerbajdzsánnak igen komoly politikai és katonai kihívással kellett szembenéznie, ami a mai napig megoldatlan kérdésként árnyékolja be a köztársaság mindennapjait, miközben igen erőteljesen meghatározza az új állam nemzeti identitását (AuCH, E-M., 2008).

A transzkaukázusi országok (Grúzia,Örményország és Azerbajdzsán) az 1990-es években azon területi keretek között kezdték meg független államiságukat, amelyeket az 1920-as években határozott meg számukra a központi szovjet vezetés Moszkvában, közvetlenül azután, hogy katonailag is megszállták a Kaukázuson túli térséget (kiszorítva ezzel az angol és török katonai erőket). Mivel a 20. század elsô két évtizedének eseményei egyértelmúvé tették a Kaukázuson túli területek formálódó nemzeti identitásait, a lenini elvek értelmében szükséges lépés volt a független grúz, örmény és azerbajdzsáni állam létrehozása. A konkrét határok meghúzása azonban a szövevényes érdekviszonyok közepette már közel sem volt egyértelmú. A korabeli bolsevik központi vezetés egyik ilyen végzetes döntésének tekinthető a többségében örmények által lakott Hegyi-Karabah Azerbajdzsánhoz csatolása.

Az 1980-as években a Szovjetunió perifériáján jelentkező etnikai jellegú feszültségek különösen a Kaukázus vidékén éleződtek ki annyira, hogy véres háborús konfliktusokat generáljanak az 1990-es években (CORNELL, S. E. 2002). Ezek egyike volt az a háború, amit a Hegyi-Karabahban élő örmények indítottak azért, hogy függetlenedjenek Azerbajdzsántól. A polgárháború egyben területi vitát is jelentett a szomszédos Örményország és Azerbajdzsán között. A fegyveres összecsapásoknak az 1994-es fegyverszünet vetett véget Hegyi-Karabah és Azerbajdzsán között. A szovjet időkben autonóm terület, amelyet közvetlen irányítás alá vont 1990-ben a bakui vezetés, de jure Azerbajdzsán része ugyan, de Hegyi-Karabah Köztársaság (Arcah) néven de facto önállósította magát és saját igazgatást épített ki (AuCH, E-M. 2008).

A háború elementáris erôvel hatott a független Azerbajdzsán többségi népének nemzeti identitására. A mindkét oldalon jelentős áldozatokkal járó összecsapások nyomán mélyültek a törésvonalak örmények és azerbajdzsánok között, erősödött az egymástól való különbözőség hangoztatása (CROISSANT, M. P. 1998). A másikkal szembeni öndefiníció révén kaptak ismét jelentőséget az iszlám tradíciók az azerbajdzsánok körében. Hegyi-Karabah azerbajdzsán lakosságának sorsa (a háborút túlélők elmenekültek, vagy elúzték ôket) a létükben való veszélyeztetettség érzésében kovácsolta össze az azerbajdzsánokat, etnikai alapot adva ezzel nemzeti identitásuknak (GASIMOV,Z. 2011a). A közös hazát veszélyeztető örmények képe pedig a nemzeti identitás területi motívumát, a szent és sérthetetlen államterület igényét hívta életre.

\section{A posztszovjet azerbajdzsán nemzeti identitás}

A második világháború utáni szovjet időszak legbefolyásosabb azerbajdzsáni politikusa, Heydar Aliev, valamint fia, Ilham Aliev révén a hatalom rendszere kisebb változásokkal tovább él a független Azerbajdzsánban is. A proletár internacionalizmus elve helyett azon- 
ban a hatalom ideológiai támasza és egyben legitimációs eszköze - ahogyan ez a szovjet érdekszféra számos más államában is megfigyelhetô - az etnikai alapú nacionalizmus.

Az egykori szovjet vezetésből lett hatalmi elit a nemzeti jelszavak hangoztatásakor visszatekint egyrészt közvetlenül a szovjet időszak elé, az első demokratikus iszlám állam létezésének időszakára. A ,demokrácia” hívó szava azonban kifejezetten a szovjet időszak sajátossága, amely a korábbi „,imperialista és zsarnok” cári hatalommal szemben definiálta saját diktatórikus hatalmi rendszerét demokratikusnak. Ugyanakkor a Szovjetuniótól való függetlenedés nemzeti jelentőségének hangoztatása révén a korábbi önálló nemzeti lét hangoztatása különösen nagy jelentőséggel bír a szovjet utódállamok körében.

Másrészt viszont a jelenlegi hatalom operál a szovjet időszakban formált kollektív emlékezet jóval régebbi időkre visszatekintő elemeivel is, ami nem csak az expanzív orosz szomszédtól, hanem a korábbi több évszázados perzsa hatalomtól is elkülöníti az azerbajdzsán népet (GASIMOV, Z. 2011b). Ebben a kontextusban viszont az altáji nyelvcsaládhoz tartozó, türk eredetú azeri nyelvnek, és a pántörök kapcsolatoknak van jelentősége, ami egyrészt a Törökországgal, másrészt a közép-ázsiai egykori szovjet tagköztársaságokkal vezetett szorosabb külpolitikai kapcsolatokhoz (SIDIKOv, B. 2008). A nyelvi dimenzió kapcsán így ismét megemlíthetjük az azeri cirill betűs írásmódjának lecserélését a latin betûs írásmódra, amely így nem csupán az orosz befolyástól való függetlenedés szimbólumaként kap nagy jelentőséget.

A hatalom által is konstruált azerbajdzsán nemzettudatban központi szerepet kapott az iszlám hit. Ez egyrészt megmutatkozik az 1990-es évek mecsetépítési lázában, aminek köszönhetóen ismét 1300 fölé nőtt a mecsetek száma. Ez a kétezres években is tovább folytatódott, így Azerbajdzsánban a mecsetek száma már meghaladta az 1700-at is (NAJAFIZADEH, M. 2012). Közülüik is kiemelkedik a szimbolikus jelentőségú Bibi-Heybat mecset. A 13. század óta létező kultikus helyet 1934-ben lerombolták, de a független állam - szakítva a szovjet múlttal - újjáépíttette 1997-ben, majd kibóvítette 2008-ban. Az épített környezet módosulása a függetlenedő hatalom és a szovjet hatalommal szemben értelmezett nemzettudat jelképeként értelmezhető.

Tehát az azerbajdzsán nemzettudatnak központi eleme az iszlám hit, annak ellenére, hogy a vallását aktívan gyakorlók köre igen alacsony (NAJAFIZADEH, M. 2012). Azerbajdzsán egy önmagát iszlám államként definiáló, szekularizált állam, ahol az iszlám tradíciók a mindennapokban viszonylag lassan születnek újjá (nem úgy, mint az épített környezetben). A városokban a muszlim jelképnek tekintett női fátyolviselés szinte egyáltalán nem jellemző, a vidéki közösségekben is inkább praktikus okokból van jelen a fejkendő. A szovjet időszak örökségeként tehát sajátos viszony fúzi az azerbajdzsáni lakosságot a valláshoz. Ugyanakkor az emberek túlnyomó többsége (több mint 90 százaléka, NAJAFIZADEH, M. 2012) muszlimként definiálja önmagát, amit a hatalom is megerősít: Azerbajdzsán deklaráltan az iszlám politikai közösség része. A mecsetépítés mellett a „,nemzeti iszlám” jelenlétének igénye hívta életre a Korán fordítását azeri nyelvre. Ugyanakkor a hatalom - szovjet örökségként - drasztikusan ellenőrzi a vallást: minden ilyen jellegú irodalom szigorú állami ellenőrzés alatt jelenhet csak meg (NAJAFIZADEH, M. 2012).

Az iszlám egy másik, nemzeti mivolthoz kapcsolható kontextusban is jelentőséget kapott az 1990-es években: a keresztény örményekkel szemben megfogalmazott nemzeti öndefinícióban. A szovjet időszakból örökölt Hegyi-Karabah egyelőre megoldatlan kihívás a hatalom számára, ugyanakkor a konstruált nemzeti öntudat egyik legfontosabb a hatalom által képviselt elemét hívta életre: a területi integritás védelmét és Azerbajdzsán szuverenitásának biztosítását az „örmény agresszióval” szemben (BRown, C. S. 2004). A folyamatosan napirenden lévő/tartott problémát ebben a kontextusban tárgyalja az azerbajdzsáni közmédia, továbbá mélyen benne él a lakosság tudatában is (BROWN, C. S. 
2004; O’LEAR, S. 2008). A fennálló patthelyzet megoldása tehát feltehetően még hosszú időre várat magára.

Ugyanakkor az azerbajdzsán nacionalizmus sajátos elemeként él a köztudatban a kettéosztott nép mítosza. A szovjet időszakban formált kollektív emlékezet egyik fontos eleme volt az a meggyőződés, hogy a két nagyhatalom, az orosz és a perzsa szándékosan osztotta ketté az azerbajdzsán népet az Arasz-folyó mentén a 19. század elején, hogy ne tudjanak erős államot létrehozni. Az egyesítés kérdése paradox helyzet elé állítják a nacionalizmus képviselőit, hiszen Hegyi-Karabah kérdésében a területi integritást hangsúlyozzák, miközben Irán felé a népek önrendelkezését hangoztató, etnikai alapú területgyarapodást szorgalmaznának. A politikai elit egyelőre ezt az ellentmondást azzal küszöbölte ki, hogy lemondott az utóbbi hangoztatásáról (BRown, C. S. 2004). Ugyanakkor folyamatosan hivatkozik a világon élő valamennyi azerbajdzsánra.

A jelenlegi azerbajdzsán önmeghatározás fontos eleme a veszteségek folyamatos szuggerálása. A koncepció alapja az egykori ún. „Nagy Azerbajdzsán”, melyet „Nagy Örményország”, illetve a perzsa kultúra elég széles területi bázisa, „Nagy-Perzsia” koncepciója ihletett (GASIMOV, Z. 2013). A mai, kisebb államterület a külső nagyhatalmak - korábban cári Orosz, Perzsa, Szovjet, ma Irán, a putyini Oroszország, illetve Örményország - ármánykodásának eredménye/eredője. Elsődleges veszteségek ként ebben a kontextusban Hegyi-Karabahot (a SZU-ból kiszakadt ország területének 15\%-a), illetve É-Iránt (ez a problematika Tebriz néven fut az azerbajdzsán táradalomban) nevezik meg. Ugyanakkor a veszteség-diskurzusokat a talis és lezg probléma is erósíti, amennyiben mindkét csoport etnikai területét kettévágja a jelenlegi Azerbajdzsán határa, így jelentős csoportjaik élnek egy tömbben Dagesztánban, illetve Iránban követlenül a határ mentén - ezzel mintegy fenntartva a területi integritásra veszélyes helyzetet (3. ábra).

A hatalom által képviselt nemzeti identitásformálásban hazához kötődő elemként jelenik meg „az anyaföld kincse”, a szénhidrogén vagyon. Az azerbajdzsáni politikai elit egyben az energiaipar legnagyobb tulajdonosa is, amely minden más gazdasági ágat meghatároz az országban. A kitermelés és feldolgozás megnyitása nemzetközi olajipari cégek előtt egyben a szimbolikus nyitást is jelentik a világ többi része felé. Az olajipar szülővárosaként emlegetett Baku az ezredfordulót követően még inkább elválik az ország többi részétől, ami az épített környezetben is szembetűnő eltérésekhez vezetett, prezentálva a fóváros és vidéke végletes elkülönülését.

Az ország olajipar révén kiépített nemzetközi kapcsolatait a szuverenitás védelmében is hangoztatja a hatalom, de az egykori Szovjetuniótól való függetlenedés fontos motívumaként is értelmezhető. Ugyanakkor az oroszországi kapcsolatok fontosságát, a szovjet örökséget hangsúlyozza az a tény, hogy Azerbajdzsán a Független Államok Közösségének is tagja, így a szomszédos Oroszországgal szoros baráti kapcsolatokat ápol.

\section{Összefoglalás}

Európa keleti felében a nemzeti identitások formálódását, illetve a nacionalizmusok megjelenését jelentősen befolyásolta a mindenkori orosz/szovjet hatalom. A Kaszpi-tenger nyugati előtere a 18. században vált az egykori Orosz Birodalom befolyási övezetévé, a látványosan növekvő területú állam központi vezetése hathatós katonai beavatkozások révén fejezte ki igényét a geopolitikában számító régióra (HERZIG, E. 1999). Az expanzív orosz hatalmi politikák keretrendszerében alakult ki a Kaukázus negatívan csengő fogalma, ami a kudarcok mellett tükrözi az itt élők hódítókkal való ambivalens viszonyát, a peremterületi lét sajátosságait. 


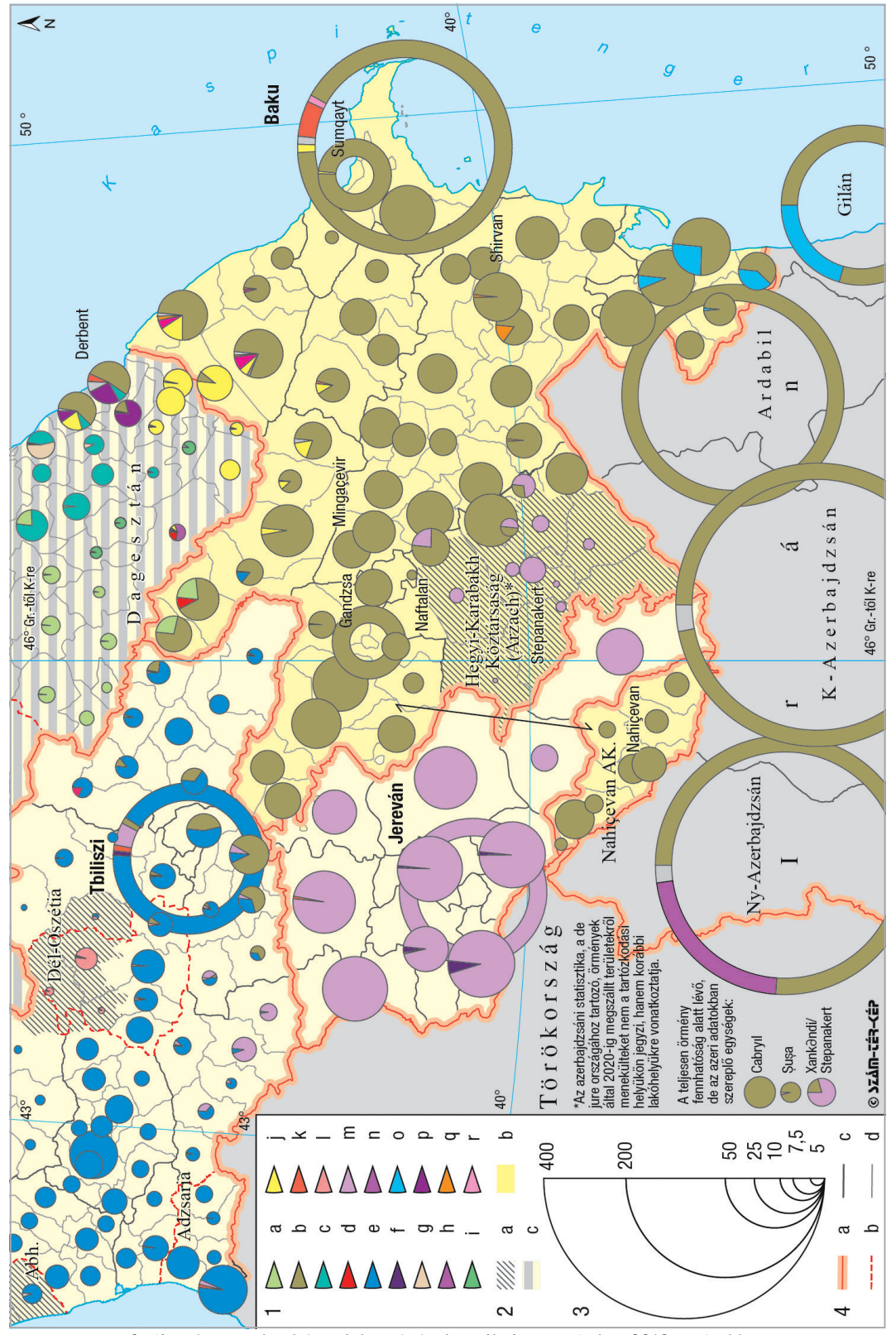

Jelmagyarázat 1-A lakosság etnikai összetétele; a- avar, b-azeri, c- dargin, d-cahur, e- grúz, f- jazid, g-kumik, h- kurd, i- lak, j- lezg, k- orosz, l- oszét, m- örmény, n- rutul, o- talis, p- tabasszaran, q- török, r- ukrán;

2- Egyéb területek; a- Örményország által 2020-ig megszállt terület, b- Azerbajdzsán területe, c- Oroszország területe; 3- A lakosság száma (10000 fó); 4- Határok, a- országhatár, b- oblaszthatár, c- rajonhatár Figure 3 Ethnic composition of the transcaucasian population in the $2010 \mathrm{~s}$

Legend 1-Ethnic composition of the population; a- Avar, b- Azeri, c- Dargin, d- Tsakhur, e- Georgians, f- Yazidi, g-Kumyk, h-Kurd, i- Lak, j- Lezgin, k-Russian, l- Ossetian, m-Armenian, n- Rutul, o- Talysh,

p- Tabasaran, q- Turk, r- Ukrainian; 2- Other territories; a- The territory occupied by Armenia until 2020, b- the territory of Azerbaijan, c- the territory of Russia; 3- Number of the population (10000 prs);

4- Boundaries, a- State boundary, b- Boundary of Autonomous territory, c- Oblast boundary, d- Raion boundary 
A rendkívül heterogén összetételú régióban a 20. században, a Szovjetunió létezésének időszakában születtek meg azok a határok, amelyek a 21. században is meghatározzák a nemzetállami lét kereteit. E határokon belül az egységes, homogén identitás kialakítása a pártállami diktatúrák időszakában is folyamatos volt, majd a rendszerváltást követően nyíltan is nemzeti jelleget öltött, amely a tágabb térség etnikai térszerkezetében is megmutatkozik. E folyamat több szempontból sajátos a szovjet utódállamban, Azerbajdzsánban.

Az azerbajdzsáni nemzettudat így az orosz, majd szovjet hatalom által szabályozott keretek között formálódott. Ugyan az azeri nyelvet beszélők Azerbajdzsán határain túl is nagy számban élnek, az azerbajdzsáni nemzeti identitás pedig kifejezetten a modern nemzetállami keretekhez kötött. A szovjet idők örökségeként az azerbajdzsáni társadalom ugyan szekularizált, nemzeti identitását mégis jelentősen meghatározza az iszlám. Mindezek alapján sajátos külpolitikai viszonyrendszer köti a világpolitikában is meghatározó három szomszédjához, Oroszországhoz, Iránhoz és Törökországhoz. Háborús konfliktusokat generáló, máig rendezetlen határvitája a szomszédos transzkaukázusi állammal, Örményországgal a gyűlöletmítoszok és a közös ellenségkép révén befolyásolja nemzeti identitását. Stratégiai nyersanyagbázisa pedig gazdasági szempontból biztosítja államterülete geopolitikai jelentôségét a 21 . században.

\title{
Köszönetnyilvánítás
}

A tanulmány a K 124291 számú, A poszt-szovjet után (?): A változó kelet-európai pufferzóna társadalmi folyamatainak földrajzi vizsgálata címú projekt keretében, a Nemzeti Kutatási, Fejlesztési és Innovációs Hivatal (NKFIH) támogatásával készült.

\author{
KŐSZEGI MARGIT \\ ELTE BTK Múvelődéstörtneti Tanszék, Budapest \\ koszegimargo@gmail.com \\ BoTTLIK ZSOLT \\ ELTE TTK Gazdaság- és Társadalomföldrajzi Tanszék, Budapest \\ agria@gmx.net
}

\section{IRODALOM}

Anderson, B. 1991/1983: Imagined Communities. Reflections on the Origin and Spread of Nationalism. Verso, London - New York.

Auch, E-M. 2008: Berg Karabach - Krieg um die “Schwarzen Berge”. In: von GupPEnBerg, M-C.-STEInBACH, U. (Hrsg.): Der Kaukasus: Geschichte - Kultur - Politik. Verlag C. H. Beck, München pp. 111-122.

Внавна, H. K. 2004 [1994]: Location of Culture. Routledge, $2^{\text {nd }}$ Edition, London \& New York, 440 p.

Brown, C. S. 2004: Wanting to Have Their Cake and Their Neighbor's Too: Azerbaijani Attitudes towards Karabakh and Iranian Azerbaijan. - Middle East Journal, 58. 4. pp. 576-596.

BRUBAKER, R. 1996: Nationlaism reframed. Nationhood and the national question in the New Europe. Cambridge University Press, Cambridge.

Croissant, M. P. 1998: Armenia-Azerbaijan Conflict: Causes and Implications. Westport, CT: Praeger, 172 p. Cornell, S. E. 1998: Religion as a Factor in Caucasian Conflicts. Civil Wars, 1. 3. pp. 46-64.

Cornell, S. E. 1999: The Nagorno-Karabakh Conflikt. Report no. 46, Department of East European Studies, Uppsala University,

CoRnell, S. E. 2002: Autonomy and Conflict. Ethnoterritoriality and Separatism int he South Caucasus - Cases in Georgia. Department of Peace and Conflict Research, Uppsala Report No. 61. 258 p. 
EriKsen, T. H. 2003: Ethnicity and Nationalism. SAGE Publications, Los Angeles - London - New Delhi Singapore.

Gasimov, Z. 2011a: The Caucasus, in: European History Online (EGO), published by the Institute of European History (IEG), Mainz 23 p.

URL: http://www.ieg-ego.eu/gasimovz-2011-en URN: urn:nbn:de:0159-2011081894

GasimOv, Z. 2011b: Zwischen Europa, Turan und Orient: Raumkonzepte in der modernen aserbaidschanischen Geschichtsschreibung und Geschichtspolitik - Jahrbücher für Geschichte Osteuropas; Neue Folge, 59. 4. pp. 534-558.

GASIMOV, Z. 2013: Aserbaidschan: Befreiung und Konflikt - der Umgang mit Verlusten in einer postkolonialen Gesellschaft In.: Hilger A.- von Wrochem, O. (Hrsg): Die geteilte Nation: nationale Verluste und Identitäten im 20. Jahrhundert Oldenburg Verlag; München pp. 135-151.

Heller, M.-Nyekerics, A. 1996: Orosz történelem II. A Szovjetunió története. Osiris, Budapest 610 p.

HerzIG, E. 1999: The new Caucasus: Armenia, Azerbaijan and Georgia. Royal Institute of International Affairs, London, $165 \mathrm{p}$.

HoRvÁt, Cs. 2011: Ethno Demographic Changes in the Caucasus 1860-1960. - Délkelet-Európa - South-East Europe International Relations Quarterly, 2. 6. 20 p. https://www.southeast-europe.org/pdf/06/DKE_06_A_K_HORVATH_CSABA.pdf

O'LeAR, S. 2008: Azerbaijan In: GunTRAm H. H.-DAvid H. K. Nations and Nationalism: volume 4. A Global Historical Overview, 1989 to Present. ABC-CLIO. pp. 1714-1721.

O'Loughlin, J.-Kolossov, V.-Radvanyi, J. 2007: The Caucasus in a Time of Conflict, Demographic Transition, and Economic Change. Eurasian Geography and Economics 49. 2. pp. 135-156.

Mutuu, S. 2003: Late Ottoman Population and Its Ethnic Distribution. In: Turkish Journal of Population Studies, 25. pp. 3-38.

NajafiZAdeH, M. 2012: Gender And Ideology: Social Change And Islam In Post Soviet Azerbaijan. - Joumal of Third World Studies. 29. 1. 81-101.

Pravikova, L.-Lazarev, V. 2005: The North Caucasus Bilingualism and Language Identity. In: Cohen, J. -McAlister, K. T.-Rolstad, K.-MacSwan, J. (ed): Proceedings of the $4^{\text {th }}$ International Symposium on Bilingualism Cascadilla Press Somerville, MA, pp. 1309-1327.

Rauf A. G. 1996: Ethnic Situation int he Caucasus. Center for Strategic Research - Republic of Turkey Ministry of Foreign Affairs 9 p.: https://sam.gov.tr/ethnic-situation-in-the-caucasus/

Sidikov, B. 2008: Aserbaidschan - Machtpoker um die Petrodollars In: von GupPEnBerg, M-C-STEInBACH, U. (Hrsg.): Der Kaukasus: Geschichte - Kultur - Politik. Verlag C. H. Beck, München pp. 49-63.

TuViKene, T. 2016: Strategies for Comparative Urbanism: Post-socialism as a De-territorialized Concept. International Journal of Urban and Regional Research. 40. 1. pp. 132-146.

Ulasiuk, I. 2013: National Minorities and Migration in Armenia, Azerbaijan, Belarus, Georgia, Moldova, Russia and Ukraine. In: CARIM-East Research Report No. 33.

YAmSKov, A. N. 1991: Ethnic Conflict in the Transcausasus: The Case of Nagorno-Karabakh. Theory and Society. 20. pp. 631-660.

\section{A térképek forrásai}

Oroszország:

Первая Всеобщая перепись населения Российской Империи 1897 г. Под ред. Н.А. Тройницкого. т. II. Общий свод по Империи результатов разработки данных Первой Всеобщей переписи населения, произведенной 28 января 1897 года. С.-Петербург, 1905. Таблица XIII. Распределение населения по родному языку.

Всероссийская перепись населения 2002, 2010 года Национальный состав населения по регионам России

Брук С. И.-Апенченко В. С. (отв. ред.) 1964: Атлас народов мира. - Издательство: М. Академии наук, Москва. 184 p.

Брук С. И.-Пучков П. И. 2010: Карта Народов (Масштаб 1:25000) (http://iamruss.ru/map-of-the-ethnic-composition-of-russia/ és http://ontheworldmap.com/russia/)

Demoskop, Weekly - (http://www.demoscope.ru/weekly/ssp/census.php?cy=0)

Population statistics of Eastern Europe \& former USSR - (http://pop-stat.mashke.org/)

Irán:

Азербайджанцы в Иране - (https://ru.wikipedia.org/wiki/Азербайджанцы_в_Иране)

Izady M. 2006-2009: Languages of Middle East (https://www.reddit.com/r/MapPorn/comments/2erlg7/detailed _map_of_languages_within_the_middle_east/)

Izady M. 2006: Linguistic Composition of Iran (http://www.farsinet.com/farsi/linguistic_composition_of_iran.html) 
Kaukázus országai:

Ethno-Caucasus - http://www.ethno-kavkaz.narod.ru/russkiy.html

Izady M. 2000: Infographs, Maps and Statistics Collection (https://gulf2000.columbia.edu/maps.shtml)

Major Muslim ethnic groups in Armenia, Iran, and the Islamic Commonwealth states.

(https://upload.wikimedia.org/wikipedia/commons/3/3a/Major_Muslim_ethnic_groups_in_Armenia\%2C_ Iran\%2C_and_the_Islamic_Commonwealth_states._LOC_92683743.jpg)

von Seidlitz, N.-Selenoy, G. L. (1896): Die Verbreitung der Armenier in der asiatischen Türkei und Transkaukasien. Dr. A. Petermann's Mitteilungen aus Justus Perthes' Geographischer Anstalt, Band 42. pp. 1-10. 